\title{
HUBUNGAN KECERDASAN NATURALIS DAN MOTIVASI BELAJAR DENGAN KEMAMPUAN BERPIKIR KRITIS PESERTA DIDIK PADA MATERI PENCEMARAN LINGKUNGAN
}

\author{
Nabilah Rahma Putri ${ }^{1)}$, Mieke Miarsyah ${ }^{2}$, Diana Vivanti ${ }^{3)}$ \\ 1,2,3 Pendidikan Biologi, Fakultas MIPA, Universitas Negeri Jakarta \\ ${ }^{1}$ email: rahmaputri1208@gmail.com \\ 2email: mmiarsyah@unj.ac.id \\ 3email:dianavivanti@yahoo.com
}

Diterima 11 Juni 2018 disetujui 16 Oktober 2018

\begin{abstract}
The skills to think critically on environmental pollution material is the skills of the learners to understand a condition that involves the process of reasoning about environmental pollution. Student's critical thinking skills is an interaction between various factors, namely naturalist intelligence and motivation learning. Student who possess critical thinking skills are as good as those naturalist intelligence and those who are motivated to learn. This study aimed to determine the correlation between naturalist intelligence and motivation learning with student's critical thinking skills in Jakarta on environmental pollution. This research was conducted at 68 Jakarta Senior High School on semester II of 2017/2018 school year. The method that was used is descriptive quantitative through correlational study. The sample used amount if 115 students of class X MIA. The result of prerequisite test finds that the data are normally distributed and homogeneous. The statistical hypothesis was done by linier regression test, liniearity test, and correlation coefficient test at $\alpha=$ 0,05 . Based on these results, it is concluded there is a correlation between naturalist intelligence and motivation learning with student's critical thinking skills on environmental pollution.
\end{abstract}

Keywords: motivation learning; naturalist intelligence; critical thinking skills

\section{PENDAHULUAN}

Pendidikan merupakan sebuah proses untuk mengembangkan potensi peserta didik dalam hal kecerdasan berpikir sehingga siap untuk bersaing di era pengetahuan yang semakin maju. Salah satu kemampuan yang ditumbuh kembangkan dalam proses pendidikan adalah kemampuan berpikir kritis. Setiap peserta didik diharapkan dapat menyelesaikan permasalahan dalam kehidupan dengan kemampuan berpikir kritis, sehingga dapat dikatakan bahwa kemampuan berpikir kritis adalah kemampuan yang penting dalam menganalisis suatu kejadian (Adeyemi, 2012).

Kemampuan berpikir kritis dapat digunakan sebagai kemampuan berpikir untuk menganalisis permasalahan lingkungan yang didasarkan pada penerapan pendidikan lingkungan.
Pendidikan lingkungan memiliki kontribusi yang besar dalam penentuan peserta didik untuk mengasah kemampuan berpikir kritis dan sikap peduli lingkungan. Selama ini ketika peserta didik dihadapkan oleh suatu masalah, peserta didik cenderung menjawab suatu pertanyaan dengan cara mengutip dari buku atau bahan pustaka lain tanpa mengemukakan pendapat atau analisisnya terhadap masalah. Bila keadaan ini berlangsung secara berkelanjutan, maka peserta didik akan mengalami kesulitan dalam mengaplikasikan pengetahuan yang diperolehnya pada kehidupan nyata (Arslan, 2012).

Kemampuan berpikir kritis diperlukan peserta didik dalam mengembangkan pengetahuannya. Selain itu, juga diperlukan dalam kehidupan bermasyarakat karena manusia selalu menghadapi permasalahan dalam 
keseharian. Permasalahan yang ada membutuhkan penyelesaian yang baik sehingga dapat membuat keputusan yang tepat. Yang disesuaikan dengan fakta dan informasi yang jelas (Quinn, 2012). Kemampuan berpikir kritis disebabkan oleh beberapa faktor yaitu kondisi fisik, motivasi, kecerdasan, perasaan, pengalaman, kebisaan dan rutinitas (Fitria, 2015).

Kecerdasan merupakan salah satu faktor yang memengaruhi kemampuan berpikir kritis. Kecerdasan tersebut yaitu kecerdasan naturalis. Kecerdasan naturalis merupakan kemampuan seseorang untuk mengidentifikasi dan mengklasifikasikan pola-pola alam beserta lingkungannya (Retnowati, 2013). Kecerdasan naturalis memiliki peranan untuk meningkatkan kepekaan peserta didik terhadap kondisi lingkungan yang menunjukkan ranah afektif peserta didik dan berkaitan dengan perilaku peserta didik terhadap lingkungan sekitar (Amstrong, 2002).

Kepekaan dan kepedulian peserta didik terhadap lingkungan menjadi hal penting dalam menjalani kehidupannya. Peserta didik perlu diajarkan tentang pentingnya menjaga alam karena saat ini banyak terjadi fenomena kerusakan lingkungan yang diakibatkan oleh ketidakpedulian manusia terhadap lingkungan. Oleh sebab itu, kecerdasan naturalis perlu dilibatkan untuk menguatkan fondasi peserta didik agar memiliki kepekaan terhadap lingkungan (Darmawan,2016). Selain kecerdasan naturalis, faktor lain yang berkaitan untuk mengasah kemampuan berpikir kritis ialah motivasi belajar.

Motivasi belajar adalah suatu keadaan batin yang membangkitkan keinginan individu untuk berupaya dalam rangka mencapai tujuannya dalam belajar (Kong, 2009). Bila motivasi belajar yang dimiliki peserta didik tinggi, maka keterlibatan kemampuan berpikir kritisnya akan semakin tinggi karena motivasi dan pemikiran kritis telah diakui sebagai elemen penting yang berkontribusi terhadap pembelajaran (Fahim, 2014). Kegiatan berpikir kritis dapat mendorong peserta didik termotivasi untuk belajar dengan gigih ketika dihadapkan dengan tantangan tugas-tugas yang membutuhkan proses bernalar sehingga menyebabkan peserta didik yang kurang termotivasi menjadi terlibat untuk belajar (McCormick, 2015). Untuk mendorong terciptanya keterlibatan kemampuan intelektual kognitif tingkat tinggi seperti pemikiran kritis, hal yang harus diperhatikan yaitu waktu yang sesuai dalam pengerjaan tugas. Selain itu, guru dapat juga dapat terlibat aktif mendorong peserta didik untuk memusatkan instruksi yang guru berikan pada kegiatan berbasis penalaran agar peserta didik temotivasi untuk belajar.

Berdasarkan hal tersebut, penelitian ini perlu dilakukan untuk mengetahui hubungan kecerdasan naturalis dan motivasi belajar dengan kemampuan berpikir kritis peserta didik pada materi pencemaran lingkungan.

\section{METODE PENELITIAN}

Metode yang digunakan pada penelitian ini adalah metode deskriptif dengan teknik survei melalui studi korelasional. Penelitian dilakukan di SMAN 68 Jakarta pada semester genap tahun ajaran 2017/2018. Pada penelitian penelitian ini terdapat tiga variabel yang akan diteliti yaitu kecerdasan naturalis dan motivasi belajar merupakan variabel bebas (X) dan kemampuan berpikir kritis peserta didik pada materi pencemaran lingkungan merupakan variabel terikat $(\mathrm{Y})$.

\section{Metode Pengumpulan Data}

Populasi target pada penelitian ini adalah seluruh peserta didik SMAN 68 Jakarta tahun pelajaran 2017/2018. 
Populasi terjangkaunya adalah peserta didik kelas X SMAN 68 dengan cara purposive sampling. Kelas $\mathrm{X}$ terdapat 8 kelas dipilih secara cluster random sampling dan terpilih 4 kelas yaitu X MIA 1, X MIA 2, X MIA 4 dan MIA 5. Jumlah peserta didik setiap kelas terdapat 36 peserta didik dan memilih 115 peserta didik sebagai sampel penelitian menggunakan simple random sampling dari responden. Jumlah sampel ditentukan menggunakan rumus Taro Yamane.

\section{Metode Analisis Data}

Teknik analisis data diuji dengan melakukan uji normalitas yang dihitung menggunakan uji Kolmogorov-Smirnov. Uji homogenitas dihitung dengan menggunakan uji bartlett. Uji hipotesis menggunakan analisis uji regresi linier sederhana untuk melihat hubungan fungsional antara dua variabel, analisis uji korelasi sederhana untuk mengetahui derajat hubungan antara variabel menggunakan rumus korelasi, analisis uji regresi ganda dilakukan untuk mengetahui hubungan kausal antara dua variabel bebas dengan satu variabel terikat, dan analisis uji korelasi ganda dengan untuk mencari besarnya hubungan dua variabel bebas bersama-sama dengan variabel terikat

\section{HASIL DAN PEMBAHASAN}

Hasil Penelitian Berdasarkan hasil penelitian terdapat tiga golongan kecerdasan naturalis dari 115 peserta didik SMAN 68 Jakarta antara lain: golongan II yaitu sangat cerdas berjumlah 37 peserta didik (4,17\%); golongan III yaitu cerdas sebanyak 66 peserta didik (58\%); golongan IV yaitu rata-rata cerdas sebanyak 12 peserta didik (10\%) seperti pada tabel 1 .
Tabel 1. Kriteria Skor Kecerdasan Naturalis.

\begin{tabular}{|c|c|c|c|c|}
\hline Golongan & $\begin{array}{l}\text { Rentang } \\
\text { Nilai }\end{array}$ & Kriteria & Juml & $\begin{array}{l}\text { entase } \\
(\%)\end{array}$ \\
\hline I & $310-345$ & $\begin{array}{c}\text { Istimewa } \\
\text { cerdas }\end{array}$ & 0 & 0 \\
\hline II & $277-309$ & $\begin{array}{l}\text { Sangat } \\
\text { cerdas }\end{array}$ & 37 & 32 \\
\hline III & $244-276$ & Cerdas & 66 & 58 \\
\hline IV & $205-243$ & $\begin{array}{c}\text { Rata - rata } \\
\text { cerdas }\end{array}$ & 12 & 10 \\
\hline V & $169-204$ & $\begin{array}{c}\text { Rata - rata } \\
\text { sedang }\end{array}$ & 0 & 0 \\
\hline VI & $126-168$ & $\begin{array}{c}\text { Rata - rata } \\
\text { kurang }\end{array}$ & 0 & 0 \\
\hline VII & $90-125$ & Kurang & 0 & 0 \\
\hline \multirow[t]{2}{*}{ VIII } & $\begin{array}{l}89-\text { ke } \\
\text { bawah }\end{array}$ & $\begin{array}{l}\text { Sangat } \\
\text { kurang }\end{array}$ & 0 & 0 \\
\hline & Jumlah & & 115 & 100 \\
\hline
\end{tabular}

Sumber: Tes WAIS-R dalam Zubaidi, 2009.

Berdasarkan hasil penelitian terdapat tiga kriteria motivasi belajar antara lain: kriteria sedang berjumlah 18 peserta didik (16\%); kriteria tinggi sebanyak 79 peserta didik (68\%); kriteria sangat tinggi sebanyak 16 peserta didik (16\%) seperti pada tabel 2 .

Tabel 2. Kriteria Interpretasi Nilai Motivasi Belajar

\begin{tabular}{cccc}
\hline Kriteria & $\begin{array}{c}\text { Rentang } \\
\text { Nilai }\end{array}$ & Jumlah & $\begin{array}{c}\text { Persentase } \\
(\mathbf{\%})\end{array}$ \\
\hline Sangat & $25 \%-40 \%$ & 0 & 0 \\
Rendah & & & \\
Rendah & $41 \%-55 \%$ & 0 & 0 \\
Sedang & $56 \%-70 \%$ & 18 & $16 \%$ \\
Tinggi & $71 \%-85 \%$ & 79 & $68 \%$ \\
Sangat Tinggi & $86 \%-100 \%$ & 18 & $16 \%$ \\
\hline
\end{tabular}

Sumber: $\quad 2013$. Berdasarkan hasil penelitian terdapat dua kriteria nilai kemampuan berpikir kritis antara lain: kriteria sedang berjumlah 18 peserta didik (16\%); kriteria tinggi sebanyak 97 peserta didik (84\%) seperti pada tabel 3 .

Tabel 3. Kriteria Interpretasi Nilai Kemampuan Berpikir Kritis.

\begin{tabular}{cccc}
\hline Kriteria & $\begin{array}{c}\text { Rentang } \\
\text { Nilai }\end{array}$ & Jumlah & $\begin{array}{c}\text { Persentase } \\
(\%)\end{array}$ \\
\hline Sangat & $0 \%-40 \%$ & 0 & 0 \\
Rendah & & & \\
Rendah & $41 \%-55 \%$ & 0 & 0 \\
Sedang & $56 \%-75 \%$ & 18 & $16 \%$ \\
Tinggi & $76 \%-90 \%$ & 97 & $84 \%$ \\
Sangat Tinggi & $91 \%-100 \%$ & 0 & 0 \\
\hline Sumber: Muhfahroyin, 2009. & &
\end{tabular}

Sumber: Muhfahroyin, 2009. 


\section{Uji Hipotesis Statistik}

Dalam penelitian ini dilakukan tiga kali pengujian hipotesis dengan menggunakan program SPSS 24.0 pada alpha 0,05 . Pengujian hipotesis tersebut yaitu:

\section{Hubungan Kecerdasan Naturalis dengan Kemampuan Berpikir Kritis}

Berdasarkan hasil pengujian model regresi linear sederhana, diperoleh nilai signifikansi (p) sebesar 0,000. Hal ini menunjukkan bahwa nilai signifikansi (p) $<\alpha$ yaitu $0,000<0,05$ yang berarti $\mathrm{H} 0$ ditolak dan dapat disimpulkan model regresi signifikan. Perhitungan model regresi linear sederhana menghasilkan model persamaan $\hat{\mathrm{Y}}=47,286+0,437 \mathrm{X} 1$ untuk kecerdasan naturalis (X1) dan kemampuan berpikir kritis (Y). Hasil pengujian linieritas menghasilkan taraf signifikasi data $(\mathrm{p})(0,751)>\alpha(0,05)$ yang berarti tolak H0. Dapat disimpulkan bahwa terdapat hubungan yang linier antara kedua variabel. Hal tersebut berarti setiap kenaikan variabel kecerdasan naturalis (X1) akan menyebabkan pula kenaikan pada variabel kemampuan berpikir kritis (Y).

Pengujian koefisien korelasi, didapatkan hasil koefisen korelasi (rxly) sebesar 0,500 yang berarti hubungan korelasi dengan kriteria cukup. Hasil dari koefisien determinasi sebesar $25 \%$. Hal ini dapat diartikan bahwa kecerdasan naturalis memberikan kontribusi sebesar 25\% terhadap kemampuan berpikir kritis peserta didik pada materi pencemaran lingkungan, sedangkan $75 \%$ berhubungan dengan faktor lain.

\section{Hubungan Motivasi Belajar dengan Kemampuan Berpikir Kritis}

Hasil uji model regresi linier sederhana didapatkan nilai signifikasi $(p)$ sebesar 0,000. Hal ini menunjukkan bahwa (p) $<\alpha$ yaitu $0,00<0,05$ yang berarti tolak
H0. Dapat disimpulkan bahwa model regresi signifikan dengan menghasilkan model persamaan $\hat{Y}=37,532+0,559 \mathrm{X} 2$ untuk motivasi belajar (X2) dan kemampuan berpikir kritis (Y).

$$
\text { Hasil pengujian linieritas }
$$

menghasilkan taraf signifikasi data (p) $(0,115)>\alpha(0,05)$ yang berarti terima HO . Dapat disimpulkan bahwa terdapat hubungan yang linier antara kedua variabel. Hal tersebut berarti setiap kenaikan variabel motivasi belajar (X2) akan menyebabkan kemampuan berpikir kritis (Y). Pengujian korelasi dan koefisien determinasi dilakukan dengan menggunakan Pearson Product Moment. Berdasarkan hasil perhitungan menggunakan program SPSS 24.0 diperoleh nilai signifikasi $(\mathrm{p})<\alpha(0,05)$ yaitu $0,000<0,05$, maka tolak $\mathrm{H} 0$ yang berarti terdapat hubungan positif antara motivasi belajar dengan kemampuan berpikir kritis. Pengujian koefisien korelasi, didapatkan hasil koefisen korelasi (rx2y) sebesar 0,631 yang berarti hubungan korelasi dengan kriteria tinggi. Hasil dari koefisien determinasi sebesar 39,9\%. Hal ini dapat diartikan bahwa motivasi belajar memberikan kontribusi sebesar $39,9 \%$ terhadap kemampuan berpikir kritis materi pencemaran lingkungan, sedangkan $\quad 60,1 \%$ berhubungan dengan faktor lain.

\section{Hubungan Kecerdasan Naturalis dan Motivasi Belajar dengan Kemampuan Berpikir Kritis}

Hasil uji model regresi linier ganda didapatkan nilai signifikasi (p) sebesar 0,000 . Hal ini menunjukkan bahwa $(\mathrm{p})<\alpha$ yaitu $0,000<0,05$ yang berarti tolak $\mathrm{H} 0$. Dapat disimpulkan bahwa model regresi signifikan dengan menghasilkan model persamaan $\hat{\mathrm{Y}}=34,241+0,472 \mathrm{X} 1+$ 0,130X2 untuk kecerdasan naturalis (X1), motivasi belajar (X2) dan kemampuan berpikir kritis (Y). 
Pengujian korelasi dan koefisien determinasi dilakukan dengan menggunakan Pearson Product Moment. Berdasarkan hasil perhitungan menggunakan program SPSS 24.0 diperoleh nilai signifikasi $(p)<\alpha(0,05)$ yaitu $0,000<0,05$, maka tolak $\mathrm{H} 0$ yang berarti terdapat hubungan positif antara kecerdasan naturalis dan motivasi belajar dengan kemampuan berpikir kritis peserta didik pada materi pencemaran lingkungan.

Hasil koefisen korelasi (rx1x2y) yang didapatkan sebesar 0,636 yang berarti hubungan korelasi dengan kriteria tinggi. Hasil dari koefisien determinasi sebesar 41,1\%. Hal ini dapat diartikan bahwa kecerdasan naturalis dan motivasi belajar memberikan kontribusi sebesar 41,1\% terhadap kemampuan berpikir kritis peserta didik pada materi pencemaran lingkungan, sedangkan 58,9\% berhubungan dengan faktor lain

\section{Pembahasan}

Berdasarkan hasil penelitian dengan menggunakan uji korelasi ganda didapatkan hasil yaitu terdapat hubungan yang positif antara kecerdasan naturalis dan motivasi belajar dengan kemampuan berpikir kritis peserta didik pada materi pencemaran lingkungan. Peserta didik yang memiliki kecerdasan naturalis yang tinggi maka kemampuan berpikir kritis yang dimiliki akan tinggi. Peserta didik yang memiliki motivasi belajar yang tinggi maka kemampuan berpikir kritisnya akan tinggi. Kecerdasan naturalis dan motivasi belajar secara bersama-sama memiliki hubungan yang positif dengan kemampuan berpikir kritis peserta didik pada materi pencemaran lingkungan.

Hasil pengujian hipotesis pertama menunjukkan bahwa terdapat hubungan yang cukup antara kecerdasan naturalis dengan kemampuan berpikir kritis pada materi pencemaran lingkungan dengan koefisien korelasi sebesar 0,500. Hal ini dikarenakan untuk dapat memiliki kecerdasan naturalis yang baik, kecerdasan tersebut perlu dibangun sejak dini. Selain itu, kecerdasan yang dimiliki dalam diri peserta didik tentunya akan berbeda-beda. Peserta didik tidak hanya memiliki satu kecerdasan melainkan terdapat delapan macam kecerdasan, namun tidak semua peserta didik dapat menguasai seluruh kecerdasan yang dimiliki secara bersamaan.

Pernyataan tersebut didukung oleh pernyataan Yaumi (2013) bahwa setiap peserta didik memiliki kapasitas terhadap delapan kecerdasan dalam dirinya, masingmasing peserta didik memiliki cara tersendiri saat menggunakan kecerdasannya karena keahlian dan kemampuan yang dimiliki setiap orang dalam melakukan aktivitas sehari-hari berbeda. Hasil penelitian lain yang mendukung penelitian ini yaitu penelitian yang dilakukan oleh Deepa (2014) mengatakan bahwa terdapat korelasi yang signifikan antara kecerdasan naturalis dengan kemampuan berpikir kritis seseorang.

Berdasarkan penilaian kecerdasan naturalis dengan instrumen tes berupa kuisioner, didapatkan hasil yaitu peserta didik dengan nilai kecerdasan naturalis tinggi memiliki kemampuan berpikir kritis yang tinggi pula. Hasil tersebut sesuai dengan pendapat yang dikemukakan Randall (2012) bahwa kecerdasan naturalis merupakan ketajaman dalam hal berpikir seseorang mengenai kepekaan terhadap gejala alam, kepekaan terhadap pelestarian flora dan fauna serta berbagai perubahan yang terjadi di alam dengan melibatkan proses bernalar yang baik agar dapat menentukan solusi untuk mengatasi permasalahan lingkungan yang terjadi.

Penelitian lain juga turut mendukung hasil penelitian ini yaitu penelitian Fitria (2015) dikatakan bahwa kecerdasan naturalis berkenaan dengan proses 
terlibatnya kemampuan berpikir kritis seseorang untuk merespon dengan baik, menyelesaikan suatu persoalan dan menghubungkan atau menyatukan satu hal dengan yang lain terhadap stimulus. Kecerdasan naturalis hanya dapat berkembang apabila peserta didik mendapat stimulus yang tepat. Semakin sering peserta didik berhubungan dengan alam, hewan, dan tumbuhan, maka kecerdasan naturalisnya akan semakin tinggi.

Menurut penelitian Husin (2012) untuk dapat mengembangkan kecerdasan naturalis, kecerdasan tersebut akan muncul ketika peserta didik memiliki banyak pengalaman hidup yang berhubungan dengan kegiatan di alam seperti melakukan pengamatan di lingkungan alam terbuka, melakukan kegiatan konservasi, mendaki gunung dan menjadi pemerhati flora maupun fauna. Sementara menurut pendapat Chase (2011) perkembangan kecerdasan naturalis peserta didik dipengaruhi oleh stimulus yang diberikan. Jenis dan pola stimulasi yang diberikan kepada peserta didik akan sangat berpengaruh pada optimalisasi potensi kecerdasan naturalisnya. Optimalisasi akan semakin terasah jika peserta didik diberi rangsangan dengan stimulus yang tepat. Rangsangan tersebut dapat berupa kegiatan yang melibatkan alam beserta lingkungannya.

Hasil yang didapatkan dari penelitian ini menunjukkan bahwa kecerdasan naturalis berkaitan dengan kemampuan mengasah pemikiran kritis terhadap fenomena alam dan lingkungan sekitarnya. Hal ini sesuai dengan pendapat Mauladin (2013) bahwa potensi seseorang untuk berpikir dan memahami alam harus dilakukan dengan kemampuan mengenali dan mengklasifikasikan tumbuhan dan hewan serta aspek lain dari lingkungannya. Salah satu potensi memahami alam tersebut termasuk dalam indikator kecerdasan naturalis yang dikemukakan oleh Yaumi tahun 2013. Kemampuan mengenali, mengklasifikasikan dan mengembangkan pengamatan kritis terhadap suatu peristiwa alam dapat dipengaruhi oleh beberapa faktor ekologis (lingkungan peserta didik).

Kemampuan berpikir kritis peserta didik berperan ketika seseorang dengan kecerdasan naturalis yang baik dihadapkan dengan persoalan yang membutuhkan penyelesaian. Persoalan yang membutuhkan penyelesaian digambarkan melalui penyelesaian soal uraian mengenai pencemaran lingkungan. Peserta didik dengan kecerdasan naturalis yang tinggi akan menjawab secara kritis persoalan tersebut. Hal ini didukung oleh pendapat Musfiroh (2013) bahwa proses kemampuan berpikir kritis merupakan salah satu komponen kecerdasan. Seseorang yang cerdas akan memiliki kemampuan untuk mengkritisi pikiran, memiliki kemampuan untuk mengarahkan dan mengubah pikiran atau tindakan.

$$
\text { Berdasarkan penjabaran tiap }
$$
indikator yang diukur pada instrumen kecerdasan naturalis dan dihitung persentase pencapaiannya, indikator ke-2 yaitu senang belajar dan berdarmawisata ke alam, kebun binatang atau ke museum mendapatkan persentase tertinggi sebesar 12,63\%. Hasil tersebut sesuai dengan pendapat yang disampaikan Randall (2012) bahwa umumnya peserta didik yang memiliki kecerdasan naturalis terutama pada pembelajaran Biologi (materi pencemaran lingkungan) adalah peserta didik yang banyak bersentuhan dengan lingkungan alam sekitarnya. Bila peserta didik senang belajar dan berdarmawisata ke alam tentunya akan banyak interaksi yang terjadi dan tidak lepas dari lingkungan alam. Seseorang yang memiliki kecerdasan naturalis selalu bertindak dalam acuan alam. Hal ini dapat dilihat dari kemampuannya melihat hubungan 
sesuatu yang dilakukan secara ilmiah, mengidentifikasi dan berinteraksi dengan proses alam.

Pencapaian tiap indikator dengan persentase terendah yaitu pada indikator ke4 senang menyiram bunga atau memelihara tumbuhan-tumbuhan sebesar $6,58 \%$. Hasil tersebut diduga dipengaruhi oleh peserta didik yang tidak secara menyeluruh menyukai dan memelihara bunga. Peserta didik lebih condong pada indikator lain dalam komponen kecerdasan naturalis. Hal ini sesuai dengan pendapat yang dikemukakan oleh Mauladin (2013) bahwa didunia nyata seseorang yang memiliki bakat kecerdasan naturalis sejak dini akan memiliki kecakapan untuk berkebun, memelihara hewan dan memiliki perhatian lebih dalam menyelamatkan alam. Tiap kategori tersebut akan terlihat dalam diri seseorang melalui pengamatan atau sikap yang dilakukan untuk menggambarkan kecondongan kecerdasan naturalis yang dimiliki.

Berdasarkan hasil pengujian hipotesis kedua menunjukkan bahwa terdapat hubungan yang tinggi antara motivasi belajar dengan kemampuan berpikir kritis peserta didik. Hal ini terjadi karena motivasi mendorong seseorang untuk dapat melakukan kegiatan yang dijadikan sebagai pergerakan positif atau negatif menuju pencapaian tujuan. Motivasi merupakan upaya untuk menimbulkan rangsangan, dorongan ataupun pembangkit tenaga untuk melaksanakan sesuatu tujuan yang telah ditetapkannya. Motivasi tercipta apabila adanya dorongan dari dirinya sendiri atau melalui orang lain untuk mencapai tujuan yang ingin dicapai. Sehingga hasil yang didapatkan yaitu motivasi belajar dapat menentukan keterlibatan kemampuan berpikir kritis peserta didik pada permasalahan pencemaran lingkungan

Penelitian yang dilakukan oleh Nuriyatin (2015) mendukung penelitian ini, dikatakan bahwa hasil analisis korelasi menunjukkan terdapat korelasi positif antara motivasi belajar dengan kemampuan berpikir kritis. Peserta didik dengan motivasi belajar yang baik, umumnya tingkat kemampuan berpikir kritisnya pun akan baik pula. Begitu pula yang dikemukakan oleh Sulistianingsih (2016) bahwa kemampuan berpikir kritis dapat menjadi indikator keberhasilan peserta didik dalam melakukan kegiatan pendidikan, sehingga kemampuan berpikir kritis harus dibangun dengan sebaikbaiknya dan didukung dengan motivasi belajar yang kuat dalam setiap pelaksanaan pembelajaran.

Berdasarkan pencapaian tiap dimensi yang diukur pada instrumen motivasi belajar dan dihitung persentase pencapaiannya, dimensi 1 yaitu arahan (direction) mendapatkan persentase tertinggi sebesar 12,63\%. Hal ini menunjukkan bahwa motivasi belajar peserta didik SMAN 68 berasal dari arahan dalam dirinya untuk bersemangat menyelesaikan tugas-tugas. Dimensi motivasi belajar dengan persentase terbanyak tersebut terdiri dari 3 indikator. Indikator 1 yaitu pemilihan tugas dan keinginan untuk belajar yang di prioritaskan dengan persentase sebesar $15 \%$; indikator 2 yaitu mengedepankan penyelesaian tugas dari kepentingan lain sebesar 19\%; indikator 3 yaitu ketepatan waktu pengumpulan tugas sebesar $13 \%$. Indikator ke-2 memperoleh persentase yang paling besar. Hal ini sesuai dengan pendapat Fahim (2014) bahwa motivasi peserta didik terlihat melalui sikap yaitu sifat antusias dalam belajar dan memberikan kapasitas dalam belajar. Mengedepankan penyelesaian tugas dari kepentingan lain sama halnya dengan memberikan kapasitas diri untuk mengutamakan belajar.

Penelitian yang dilakukan oleh Sardiman (2016) juga turut mendukung 
penelitian ini. Penelitian tersebut mengatakan bahwa bila motivasi belajar yang dimiliki peserta didik tinggi, maka keterlibatan kemampuan berpikir kritisnya akan semakin tinggi karena motivasi dan pemikiran kritis telah diakui sebagai elemen penting yang berkontribusi terhadap pembelajaran. Ketika seseorang dihadapkan dengan soal-soal berbasis analisis dan terdorong antusias untuk menjawab soalsoal tersebut, hal ini dapat menunjukkan adanya motivasi belajar yang tinggi dalam dirinya untuk mencapai tujuannya dalam belajar.

Dimensi arahan menjadi salah satu hal yang penting untuk mendorong motivasi seseorang. Menurut Colquitt (2011) arahan (direction) berarti motivasi seseorang ketika melakukan usaha yang sudah ada dan sudah dilakukan, diarahkan ke suatu tujuan, misalnya tujuan untuk mendapatkan nilai yang memuaskan. Peserta didik yang memiliki motivasi belajar, juga memiliki ketekunan dalam menghadapi tugas sesuai dengan arahan yang berasal dari dalam diri (instrinsik) ataupun arahan dari luar (ekstrinsik), ulet menghadapi kesulitan (tidak lekas putus asa), lebih senang bekerja mandiri dan senang mencari serta memecahkan masalah soal-soal.

Berdasarkan pengukuran motivasi belajar dengan menggunakan kuisioner motivasi belajar, diperoleh hasil yaitu dimensi intensitas merupakan dimensi dengan hasil persentase terendah sebesar 20\%. Dimensi intensitas terdiri dari dua indikator. Indikator 1 yaitu semangat dalam mengerjakan tugas dengan persentase sebesar 12\%, sementara indikator 2 yaitu berusaha memahami tugas yang diberikan mendapatkan persentase sebesar $8 \%$. Hal ini menunjukkan bahwa seseorang yang memiliki semangat belajar belum tentu menunjukkan bahwa ia memahami tuntutan tugas tersebut. Motivasi tersebut sampai pada batas melakukan pergerakan positif menuju pencapaian tujuan. Untuk dapat memahami tugas yang diberikan membutuhkan dorongan motivasi secara intensif untuk mencapai tujuan. Pernyataan tersebut didukung oleh penelitian yang dilakukan Fitria (2015) mengemukakan bahwa motivasi merupakan upaya untuk menimbulkan rangsangan, dorongan ataupun pembangkit tenaga untuk melaksanakan sesuatu tujuan yang telah ditetapkannya. Motivasi tercipta apabila adanya dorongan dari dirinya sendiri atau melalui orang lain untuk mencapai tujuan yang ingin dicapai.

Hasil pengujian hipotesis yang ketiga membuktikan bahwa kecerdasan naturalis dan motivasi belajar bersamasama memiliki hubungan tinggi dengan kemampuan berpikir kritis peserta didik pada materi pencemaran lingkungan. Hal ini dikarenakan kedua elemen yaitu kecerdasan dan motivasi merupakan faktor yang mempengaruhi kemampuan berpikir peserta didik. Hasil penelitian ini didukung oleh Ducan (2000) bahwa kemampuan berikir kritis memiliki korelasi positif dengan motivasi dan kecerdasan seseorang. Hal ini menunjukkan bahwa kecerdasan naturalis dan motivasi belajar memiliki peranan penting dalam proses kemampuan berpikir kritis peserta didik dengan koefisien korelasi sebesar 0,636.

Menurut penelitian yang telah dilakukan oleh Fitria (2015) kemampuan berpikir kritis dipengaruhi oleh berbagai faktor diantaranya adalah kondisi fisik, motivasi, kecemasan, kebiasaan dan rutinitas, perkembangan intelektual atau kecerdasan, perasaan dan pengalaman. Kecerdasan naturalis dan motivasi belajar merupakan bagian dari faktor yang mempengaruhi kemampuan berpikir kritis. Kecerdasan naturalis akan mendorong seseorang untuk lebih peka terhadap permasalahan yang terjadi disekitar seperti permasalahan lingkungan. Permasalahan 
tersebut membutuhkan solusi yang tepat sehingga perlu melibatkan proses berpikir tingkat tinggi salah satunya yaitu berpikir kritis.

Peserta didik SMAN 68 Jakarta memiliki kemampuan berpikir kritis dalam kriteria tinggi yang digunakan untuk mencari solusi ketika dihadapkan oleh suatu permasalahan. Hal ini didukung oleh kecerdasan naturalis dan motivasi belajar peserta didik yang cukup tinggi. Bila peserta didik menunjukkan kemampuan berpikir kritis yang rendah biasanya terjadi pada peserta didik yang memiliki motivasi rendah di dalam pembelajaran. Peserta didik yang memiliki motivasi rendah merasa tidak tertarik untuk mengkritisi sesuatu yang berhubungan dengan pembelajaran. Hal ini sejalan dengan pendapat Lay (2011) bahwa motivasi belajar peserta didik dipandang sebagai prasyarat yang diperlukan untuk kemampuan berpikir kritis.

\section{SIMPULAN}

Hasil penelitian menunjukkan bahwa terdapat hubungan positif antarakecerdasan naturalis dengan kemampuan berpikir kritis peserta didik pada materi pencemaran lingkungan, terdapat hubungan positif antara motivasi belajar dengan kemampuan berpikir kritis peserta didik pada materi pencemaran lingkungan dan terdapat hubungan positif antara kecerdasan naturalis dan motivasi belajar dengan kemampuan berpikir kritis peserta didik pada materi pencemaran lingkungan. Perlu dilakukan kembali faktorfaktor psikologis yang belum termasuk dalam penelitian ini agar cakupan mengenai faktor psikologis lebih luas dan mendalam. Selain itu, instrumen yang digunakan sebagai alat ukur kecerdasan naturalis, motivasi belajar dan kemampuan berpikir kritis dapat dibuat lebih spesifik dan detail.

\section{DAFTAR PUSTAKA}

Adeyemi, S. B. (2012). Developing Critical Thinking Skills in Student: A Mandate for Higher Education in Nigeria. European Journal Of Educational Research, 1(2), 155-161.

Armstrong, T. (2002). 7 Kind of Smart (Menemukan dan Meningkatkan Kecerdasan Anda berdasarkan Teori Multiple Intelligences). Jakarta: Gramedia Pustaka Utama.

Arslan, S. (2012). The Influence of Environmental Educational on Critical Thinking and Environmental Attitude. Procedia-Social and Behavioral Sciences, 1(55), 902-909.

Chase, S. (2011). A Field Guide to Nature as Spiritual Practice. Michigan: Wm. B. Eerdmans Publishing Co.

Colquitt, J. C., Jeffry, A. L., \& Michael, J. W. (2011). Organizational Behavior: Improving Performance and Commitment in The Workplace. New York. Mc Graw Hill Companies, Inc.

Darmawan, H. N. (2016). Profil Pembelajaran IPA berbasis Teori Kecerdasan Naturalis. Jurnal Mutiara Pendagogik, 1(2), 58-66.

Deepa, A. (2014). Relationship Between Multiple Intelligences and Criticak Thinking of B,Ed. Students With Reference to Locality. International Journal of Informative and Futuristic Research, 1(14), 28-33.

Duncan, T. (2000). Critical Thinking and Its Relationships to Motivation, Learning Strategies and Classroom Experience. Education Resources Information Center, 1(1), 31-42.

Fahim, M. (2014). The Relationship Between Motivation and Critical Thinking Ability Of Iranian Efl Learners. International Journal of 
Language Learning and Applied Linguistics World, 5(2), 605-619.

Fitria, K., Suastra W., \& Subratha N. (2015). Analisis Kualitatif Kemampuan Berpikir Kritis Siswa Kelas X SMAN 1 Singaraja Dalam Pembelajaran Fisika. Jurnal Jurusan Pendidikan Fisika, 2(1).

Kong, Y. (2009). A Brief Discussion on Motivasion and Ways to Motivate Students in English Language Learning. International Education Studies, 2(2), 145-148.

Lay, E. (2011). Critical Think: A Literature. Cambridge, MA: MIT Press.

Mauladin, D. 2013. The Effect of Learning Methods and Environmental Knowledge on Age 5-6 Naturalistic Intelligence (Experiment at ARRidho Nature Kindergaten Group B Tembalang Semarang). Asia Pacific Journal of Multidisciplinary Research, 1(1), 75-88.

Maryanto, L., Setyowati, N., \& Mugiarso, H. (2013). Meningkatkan Motivasi Belajar Siswa Melalui Layanan Penguasaan Konten dengan Teknik Bermain Peran. Indonesian Journal of Guidance and Conseling: Theory and Application, 2(3), 41-48.

McCormick, J. N. (2015). Engganging Students in Critical Thinking and Problem Solving: A Brief Review of the Literature. Journal of Studies in Education, 5(4), 100-113.

Muhfahroyin. (2009). Memberdayakan Kemampuan Berpikir Kritis Siswa Melalui Pembelajaran Konstruktivistik. Jurnal Pendidikan dan Pembelajaran, 16(1).

Mufiroh. T. (2013). Perkembangan Kecerdasan Majemuk. Jakarta: Universitas Terbuka.
Nuriyatin, S. (2015). Hubungan Berpikir Kritis dan Motivasi Belajar Melalui Temuan Terbimbing. Jurnal Edukasi Kajian Ilmu Pendidikan, 1(2), 181196.

Quinn, E. C. (2012). Studies on Critical Thinking for Environmental Ethics. Lincoln: Nebraska.

Randall, T. (2012). Asessment of Change in Conservation Attitudes Through Zoo and Aquarium Education. Ize Journal, 48(2), 13-15.

Retnowati, R. (2017). The Effect Of Environmental Teaching Method And The Level Of Natural Intelligence On The Environmental View of The Students Behavior. International Journal Of Science Education, 1(1).

Sardiman. (2016). Interaksi dan Motivasi Belajar Mengajar. Jakarta: Rajawali Pers.

Sulistianingsih, P. (2016). Pengaruh Kecerdasan Emosional dan Motivasi Belajar Terhadap Kemampuan Berpikir Kritis Matematika. Jurnal Kajian Pendidikan Matematika, 2(1), 129-139.

Yaumi, M. (2013). Pembelajaran Berbasis Multiple Intelligences. Jakarta: Dian Rakyat.

Zubaidi, A. (2009). Tes Inteligensi. Jakarta: Mitra Wacana Media. 